\title{
Finding Positive Aspects of the Negative Situation with Reference of Ruskin Bond's select Short Stories
}

\author{
Ms. Revathy M
}

\author{
Assistant professor, Veltech Hightech Dr.RR Dr.SR Engineering College, Avadi, Chennai, Tamil Nadu, India
}

\begin{abstract}
Today, human is facing a lot of psychological disorders in the cost of missing parental care, situation and state of being unsupported. A negative situation may impact the human emotions and stresses psychologically. Everyone has to face various negative situations, our mind provides the ability of being positive or negative, even though surroundings, people around and the environment lead the mind in a particular extent whether optimist or pessimist. Considers the negative situation as common and tries to draw it positive is extremely superior. Taking two of Ruskin Bond's stories, identify the protagonist characters, especially children change the pain of single parented or cared less into responsibility and supporting others.

Keywords- positive aspects, negative situation, Ruskin Bond.
\end{abstract}

\section{INTRODUCTION}

Similarly, a child could not learn ethics, basic knowledge and protected-feel in the absence of fathers and the absence of motherly love will lead the child to an isolated situation reducing the capability of thinking normally compared to common child with parents. Even a single parent handling child may lose few good characteristics or knowledge due to the loss of the other side. According to the report of "Australian social trends, 2007”, single parented child or orphans faces a variety of psychological problems. Bond achieves healing emotional problems with love and care.

'The woman on platform 8 '

The story "The woman on platform 8 " is a master piece of Ruskin Bond which depicts the attitude of the child 'Arun' towards the stranger lady. The story revolves around the loneliness of the little protagonist Arun and the stranger's unblended affection. Arun, who is tired of looking the unfriendly surroundings with the eyes of emptiness, reached the station early to get his train at the actual time. A strange woman appeared with the question if he was all alone. The silence of Arun grandly welcomes her without hesitation.
She takes him for having snacks and making conversation with him. He accepts her as a mother for the question of Sathish's mother 'if she is arun's mother'. Finally, the emotional event ends with the touched words "good bye mother" by Arun.

The child having cared less may get depressed or emotionally weak in continuity with the same situation, but the story of Bond creates positive aspects in loss of parental care. He made the reader to hope that the angel is always exists to take care of orphans, single parented and lost parental care. If an isolated child believes that there is God to protect them, the child must be grown positively. Bond applies the concept of love from unknown will automatically find the people those who cared less and helpless. The appearance of the stranger woman symbolizes the angel with all the characteristics. She appears suddenly to retrieve him from the emptiness and made him trusted that there is someone who loves him so much. Getting snacks for child and send off warmly are the qualities of mother that every child expects to have often, unless the basic desires being experienced there are possibilities of psychological stresses. Being a small boy, Arun understands the love of a strange woman did not last long and says bye whole heartedly with the cheerful memories to remember in difficult time.

"A Long walk with granny"

The story "A long walk with granny" explores the strongest mental ability and responsibility of the little boy 'Mani'. Having no mother, Mani has been growing under the shadow of granny who replaces his mother position. Granny has an old pair of spectacles wore and could not see her grandson whom she love the most. Mani's father ordered for a new pair of spectacles, but granny hesitated to get it thinking not to leave Mani alone as it is two days journey. Finding a solution, Mani told that he would accompany her and Mani's father assured to do so. Granny and the little boy Mani started travelling to Mussoorie, the nearer town 
for getting new pair of glasses. They stayed in Mani's uncle's house on the first night of the journey, the next morning Mani has taken bath in Sarayu River and again both continued their journey walking and climbing mountains. Since hotels are expensive, they stayed in Dharamshala at night, a place to stay free. Granny and Mani reached the hospital and bought a new pair of glasses as planned. After wearing the new glasses Granny could see the loved grandson and the nature which she longed to identify before. At the time of returning through bus, feeling tired everyone started sleeping except Granny. She is totally filled with happiness and enjoyed the greenly environment. Here, Granny represents the angel who is there to protect Mani. Mani would be left alone after his mother's death; granny saves him with the motherly love and holds him from breaking down. He did not take his life into misery about his mother's death and accepts his Granny ardently. Being a little boy, he accepts responsibility to take his granny town for getting glasses. Till returning to home, Mani says nothing like feeling unwell to walk or uncomfortable of staying in Dharamshala. Eyes of Granny were Mani and the heart of Mani was granny in the entire journey. When the bus could not go further due to landslide, they decided to continue the journey and Mani preferred it only for the sake of getting a new pair of glasses to spot his Granny seeing everything. His love and affection was awarded through a new pair of shoes that shows small things make children happy, they won't look for cost but things and the provider. The story prefers to set the background in the village as the nature consists main part of solving psychological problems, constructed town did not cause chance to divert the concentration from loneliness or depressed state. Nature welcomes the children to make use of all the wealth with demanding nothing in return.

\section{CONCLUSION}

Human life depends on the little happiness that experience in everyday life. For example, an entire day runs happily when it started from an early morning kiss of mother. The technique of balancing the loss of parental love through motherly love of stranger woman works in 'The woman on platform 8' Bond's children characters will not be guided in negative way and they will find a better way themselves to live as good and affectionate as Bond. The children's characters in Bond stories did not express their emotions in the way of frustration but sad and fearful. They will not hurt others talking worse or getting things selfishly at any cost. Bond always portrays the characteristic of showing love to unknown, expecting nothing in return. None can express the lonely feeling as much as Bond. In his early stage, Bond found love in everything to lead a normal life. He is not familiar with frustration as the person who had hurt does not like others hurt. Children (Characters) of Bond are responsible and lovable who knows how to solve their problems in the positive way.

\section{REFERENCES}

[1] Bond, Ruskin. (2004). Bond Collection for Children. New Delhi, ND: Penguin Books.

[2] ---. (2014). The Room of Many Colours [A Treasury of stories for children]. Haryana, Haryana: Penguin Group.

[3] ---. (2012). The Adventures of Rusty [Collected stories]. New Delhi, ND: Penguin Books.

[4] Ruskin Bond. (2019, Jan 17). https://en.wikipidea.org/wiki/ruskin-bond

[5] One Parent Families. (2008, July 23). http://www.abs.gov.au/AUSSTATS/abs@.nsf/0/F4B1 5709EC89CB1ECA25732C002079B2?opendocument 